\title{
A Virtuoso Nun in the North: Situating the Earliest-known Dated Biography of a Buddhist Nun in East Asia
}

STEPHANIE BALKWILL

University of Winnipeg

s.balkwill@uwinnipeg.ca

Abstract: This paper introduces and critically discusses the earliest dated biography of an East Asian Buddhist nun that is known to us, and also provides a complete annotated translation of said biography. The text in question is the entombed biography and eulogy (muzhiming 墓誌銘) of a Buddhist nun whose name was Shi Sengzhi 釋僧芝 (d. $516 \mathrm{CE}$ ). Sengzhi held high positions at the court of the Northern Wei 北魏 (386-534 CE) and on her death was given an imperial burial that included the commissioning of an entombed biography. That biography is the only source that attests to Sengzhi's life and it tells the rare story of how Sengzhi modelled a new form womanhood on the rise in her time: An elite Buddhist womanhood which was renunciatory but not eremitic. By analyzing Sengzhi's life and works, the paper argues that the study of entombed biography sufficiently challenges prior understandings of Buddhist renunciation for women by locating and historically contextualizing the precise moment of the earliest attestation of Buddhist nuns in China.

Keywords: Northern Wei, entombed biography, renunciation, Medieval China

DOI: https://dx.doi.org/10.15239/hijbs.03.02.07 


\section{Introduction: Who was Sengzhi?}

The entombed biography and eulogy (muzhiming 墓誌銘) of the late fifth/early sixth century Buddhist nun, Shi Sengzhi 釋 僧芝 (d. $516 \mathrm{CE}$ ) contains the earliest-known dated biography of a Buddhist nun that we have for all of East Asia. Dated to 516 of the Common Era, the entombed biography is from China's Mount Mang 亡ا阝, which, just outside of Luoyang 洛陽, has served as the site for the imperial mausoleums of a number of Chinese dynasties. The very location of Sengzhi's tomb, therefore, reveals an intriguing historical reality: Sengzhi was both a Buddhist nun and a courtier. In fact, Sengzhi may have been one of the Northern Wei's (386-534 $\mathrm{CE})$ longest-serving court members. Appointed in 477 of the Common Era by Empress Dowager Wenming 文明 (d. $490 \mathrm{CE}$ ), Sengzhi attended the court's move from Datong 大同 to Luoyang, where she became Emperor Xuanwu's 宣武 (r. 499-515 CE) favourite teacher of the Buddhist law. From this position of influence, Sengzhi was able to have her own niece appointed at court. Rather infamously, that niece would also go on to become a favourite of Xuanwu, bearing him a son and ascending to her own regency government as Empress Dowager Ling 靈 (d. 528 CE) after the emperor's death. Sengzhi died in the very year of her niece's seizure of ultimate power. That year was 516 of the Common Era and, by that time, Sengzhi had served the court for thirty-nine years-an almost unheard-of career for a servant of a court so unstable as that of the Northern Wei. As we will see in this study, both her gender and her religion contributed to her ability to serve the court for as long as she did.

Though the earliest, Sengzhi's entombed biography is not the only sixth century entombed biography of a Buddhist nun from Mount Mang. So far, the site has revealed four entombed biographies of Buddhist nuns from the late Northern Wei, all of them buried during the reign of Sengzhi's niece, the Empress Dowager Ling. In chronological order by year of death, they are: 


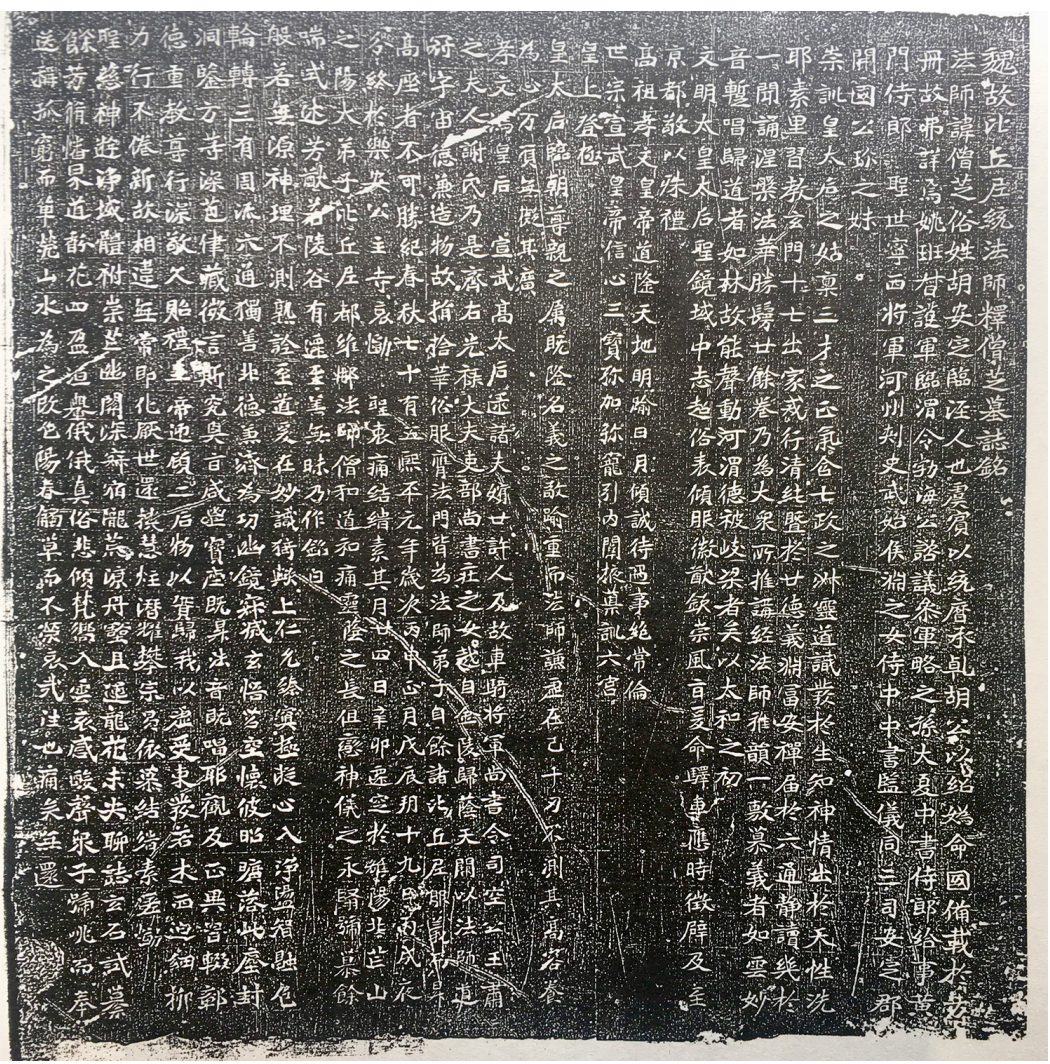

FIG. 1 The muzhiming of the Wei Superintendent of the Bhikșunis, the Dharma Master, Shi Sengzhi 魏故比丘尼統法師釋僧芝墓誌銘. Zhao and Zhao, Heluo muke shiling, 20.

1. From 516, the entombed biography of Shi Sengzhi (Figure 1), who died in the Nunnery of the Le'an Princess (le'an gongzhu si 樂安公主寺);

2. From 518, the entombed biography for the Nun Ciyi 慈義 from the imperial nunnery of the Northern Wei, the Jeweled Radiance (Yaoguang 耀光), ${ }^{1}$ otherwise known as Xuanwu's official empress, Empress Gao 高, whose death was likely at

1 Tomb Memorial of Gao Ying, Empress to Shizong 世宗后高英墓誌, transcription from Zhao, Han Wei Nanbeichao muzhi buibian, 102. 
the hands of Empress Dowager Ling and in retaliation for her own assassination attempt;

3. From 524, the entombed biography of the nun Ciqing 慈慶, likely also from the Jeweled Radiance Nunnery; ${ }^{2}$

4. From 529, the entombed biography of a princess from the Tuoba 拓拔 royal family who spent her life trying to cultivate the Buddhist path despite having to marry twice. ${ }^{3}$

These three other women who identified as Buddhist nuns (biqiuni 比丘尼) and were buried alongside Sengzhi at Mount Mang all partook of a certain form of religious monasticism for women of the period that has been studied: the widow turned nun. ${ }^{4}$ Remarkably, however, these three entombed biographies are the earliest dated attestations of such a phenomenon that have yet surfaced across the entirety of East Asia. As for Ciqing's status as a widow, her entombed biography tells us that she was the wife of a rebel leader who was brought into the menial service of the court after her husband's rebellion was quashed. From this low rank, she rose to take on roles of great responsibility in the women's chambers and 'left home' (chujia 出家) as part of her transition from rebel wife to female courtier-a transition to a form of Buddhist womanhood that enabled her rise to elite status. As for Ciyi's widowhood, her biography is largely void of language that might point to her strong Buddhist affiliation and simply tells us that she became a nun after becoming a widow. The text says: 'After the Emperor died, she determinedly aspired to the Gate of the Way, left normal custom, and became a nun'.5

2 The muzbiming of the Northern Wei bbikșuñ Ciqing (Wang Zhong'er), dated the seventh day of the fifth month of the fifth year of the Reign of Gleaming Orthodoxy (June 23, 524 CE) 魏故比丘尼慈慶 (王鍾兒) 墓志銘 (正光五年五 月七日), transcription from Zhao, Han Wei Nanbeichao muzbi buibian, 146.

3 The muzhiming of the bhikșnī of the Yuan family from the Great Awakening Nunnery 大覺寺比丘元尼墓誌銘, transcription from Zhao, Han Wei Nanbeichao muzhi buibian, 261.

4 Chikusa, 'Formation', 3-20.

5 Zhao, Han Wei Nanbeichao muzhi buibian, 197. 
Indeed, Ciyi was an empress who became a nun after the death of her husband, Emperor Xuanwu, and likely as a means of retaining social status and personal safety. Finally, as to the widowhood of the Tuoba Princess who carried the dharma name Zhishou 智首, her biography details her strong desire to lead the life of a Buddhist nun just as it chronicles how she was forced to marry twice. The biography further tells us that while married she lived the life of a nun at home by refusing luxuries and giving herself over to menial work such as cleaning and the care of her step children and that only after the death of her second husband was she able to adopt the rules of Buddhist discipline and take up residence in a small nunnery where she soon became sick and died.

Though Sengzhi shares the circumstances of her tomb and burial with these three other women who were of the imperial elite and who were recognized as Buddhist nuns, her life and her biography are markedly different than theirs. Unlike all of the others who were court women first and nuns second, Sengzhi came to court as a Buddhist nun. Her renunciation is not related to any misadventures in her marital life as she is never recorded to have been married. For Sengzhi, as we will see, it was her reputation as an eminent Buddhist nun that brought her to court and not the potential loss of courtly status through the death of a male partner that forced her into the imperial nunnery. Sengzhi was a Buddhist nun as her primary vocation and was given a number of honours in this role. It may also have been that her status as a Buddhist nun allowed her a degree of independent mobility that facilitated her move to court, of which we are unaccustomed to seeing in women of the medieval period. Her biography tells us that Sengzhi traveled far and wide in the service of the Buddha and enjoyed trans-regional connections with Buddhists in the southern dynasty of the Liu-Song 劉宋 (420-479 CE), perhaps even being ordained there. In sum, Sengzhi's story is the earliest we have that documents the rise of a new type of womanhood in East Asian society: virtuosi Buddhist womanhood. This form of womanhood is connected to the Buddhism of elite court widows because both types of women shared the same physical space, the court and its nunnery; however, it is also distinct from the Buddhism of court widows because it is the product of a quite different motivation for 
monastic renunciation. Unmarried yet virtuous, prestigious at death but not at birth, Sengzhi is a case study in the types of social opportunities that the arrival of Buddhism in China brought to the lives of women. In her case, the longevity and prestige of her position at court was rooted in her own positionality as an unmarried woman appointed at court not through marriage, but through religion. The following translation and study will focus on just how Sengzhi came to hold this role in her life. In other words, by showing how Sengzhi came to be in possession of the ranks that she did, this study aims to draw attention to the rarity of her very existence. Arguing that Sengzhi was unique in her time, this study seeks to both situate Sengzhi as an example of early forms of renunciation for women in China while also showing that-far from leading eremitic lives-virtuosi Buddhist nuns were able to leverage their Buddhist identity into surprising places.

\section{Translation: Sengzhi’s Life Story}

The Entombed Biography and Eulogy of the Northern Wei Superintendent of the Nuns and Dharma Master, Shi Sengzhi' ${ }^{6}$ 魏故比丘尼統法師釋僧芝墓誌銘

The Dharma Master's honoured name was 'Zhi' and her secular family name was ' $\mathrm{Hu}$ ' and she was from Linging in Anding. ' As the years went by, $\mathrm{Yu} \mathrm{Bin}{ }^{8}$ handed down his position and then Duke $\mathrm{Hu},{ }^{9}$ by continuing

6 In general, this translation follows the edited version of the epigraph published by Wang 'Beiwei Sengzhi muzhi kaoyi'. However, I have chosen to retain hard breaks in the lines of text as they appear on the epigraph itself as, I feel, there are semantic reasons for the breaks that should be retained in the translation.

7 Modern day Zhenyuan 鎮原 county in Gansu 甘肅 province.

$8 \mathrm{Yu}$ Bin 虞覔, or Dan Zhu 丹朱, is the supposed son mythical sage king Yao 堯 who was passed over for succession due to his incompetence and, instead, set up his territory in the state of Yu. The inclusion of this narrative in the lineage section of the biography should be read as an effort to embed the family clan within the ancient rulers of Chinese history and is reminiscent of the Book of the 
the Gui ${ }^{10}$ lineage, governed the kingdom. A thorough account [of this] is in the classical writings and therefore is not detailed herein. ${ }^{11}$ [Sengzhi] was the descendent of $[\mathrm{Hu}]$ Lüe, the Protector General Who Oversaw the Yao troops, ${ }^{12}$ the Director of Linwei, ${ }^{13}$ Duke of Bohai, and Administrative Advisor. She was the daughter of [Hu] Yuan (d.u.), the Attendant Gentleman of the Secretariat for Great Xia 大夏 $(417-431),{ }^{14}$ the Palace Attendant,

Weis (Wei shu 魏書) assertion that the Tuoba are themselves descendants of the Yellow Emperor (Wei shu 1.1).

9 Duke Hu, also known as Duke Hu of Chen 陳 (b. 1082 BCE), was the first ruler to govern the territory of Chen and may have introduced that family name to Chinese history. Duke Hu is said to be a descendent of Yao and Shun 舜.

10 Gui is both the family name of Duke Hu and, according to the Han-dynasty Dictionary, the Shuowen jiezi 說文解字 [Investigating the Origins of Chinese Characters], is also the name of the traditional territory where Shun resided.

11 Though the text here tells us that a thorough account of this is found in classical texts, the truth is not quite so clear. Wang Shan provides a discussion of this problematic lineage of the Hu Clan, see Wang, 'Beiwei Sengzhi muzhi kaoyi', 89. The point with this ancestral lineage is very clearly an attempt at writing the $\mathrm{Hu}$ Clan from Anding - the Hu Clan of the Empress Dowager and her father, $\mathrm{Hu}$ Guozhen-into legitimate forms of Han Chinese history. This is noteworthy for Sengzhi died in $516 \mathrm{CE}$, the very year that the Empress Dowager made her move to the throne to rule behind her son, the legitimate Tuoba male ancestor.

12 According to Hucker, the title of 'Protector General' was given to an individual responsible for presiding over submitted alien peoples in Western China (Hucker, Dictionary, 539). That Hu Lüe was the Protector General of the Yao troops makes historical sense for it was the ethnically non-Chinese Yao clan who ruled over the Later Qin 後秦 (384-417 CE) dynasty-a short lived, northern dynasty toppled by the Xianbei Xia 夏 dynasty (407-431 CE), which, as we will see, Sengzhi's relatives also served.

13 Linwei 臨渭 is a district in modern-day Shaanxi 陝西.

14 The reference of the Great Xia, here, is a specific reference a short-lived, northern dynasty of the Sixteen Kingdoms, the Xia ruled by Xiongnü Helian 赫連 family. The Hu family evidently served that dynasty until its collapse and then, once the Empress Dowager came to court, was able to serve the new dynasty of the Northern Wei. 
General who Thoroughly Understands the World and Pacified the Four Quarters, the Regional Inspector of Hezhou, and the Marquis of Wushi. ${ }^{15}$ She was the younger sister of [Hu Guo] Zhen ${ }^{16}$, Palace Attendant, Supervisor of the Secretariat with Authority Equal to that of the Three Offices, and the Dynasty-founding Duke of Anding Commandery. 法師諱芝, 俗姓 胡, 安定臨經人也. 虞實以統曆承乹, 胡公以紹媯命國, 備載於方/冊, 故弗 詳焉. 姚班督護軍, 臨渭令, 勃海公 諮議㕘軍略之孫, 大夏中書侍郎, 給事 黃/門侍郎, 聖世寧四將軍, 河州刺史, 武始候淵之女, 侍中, 中書監, 儀同 三司, 安定郡/開國公珎之妹./

The aunt of the Venerating the Teachings Empress Dowager, ${ }^{17}$ [Sengzhi] was endowed with the true vitality of the three capabilities ${ }^{18}$ and embraced the refined energy of the seven governances. ${ }^{19}$ Her knowledge

$15 \mathrm{Hu}$ Yuan holds titles that confer on him regional authority in military and governance; however, his titles place him closer to his ancestral home. As Regional Inspector (cishi 刺史) of Hezhou 河州 (modern day Linxia 臨夏 city, Gansu), he would have been responsible for overseeing all administrative matters in the area. He held these posts under the Xiongnü Xia kingdom.

$16 \mathrm{Hu}$ Guozhen was the father of the Empress Dowager Ling and was brought to court by her to serve as an official. He has a biography in the Book of the Wei (Wei shu 92.1833-6).

17 The previously discussed Empress Dowager Ling. The reference to her being the 'Venerating the Teachings' Empress Dowager suggests an official title of some sort. The Book of the Wei records that she lived in the Palace of Venerating the Teachings (Wei shu 31.743) where there were also official guards of the place called 'Guards of Venerating the Teachings' (Wei shu 31.743) and, finally, that there was also a 'Venerating the Teachings Buddhist Monastery' where the puppet emperor, Emperor Jiemin 節閔 (r. 531-532 CE), was held at the end of the dynasty (Wei shu 21.278).

18 According to the Book of Changes' discussion of the trigrams, the 'Three Capabilities' (sancai 三才) are heaven, earth, and man, each of which possesses two qualities: for heaven, there is yin and yang; for earth, there is softness and hardness; for man, there is benevolence and righteousness. To be endowed with all such things, therefore, is akin to saying that Sengzhi is replete with every quality that founds and sustains the harmony in the world.

19 It is unclear what exactly the 'Seven Governances' or qizheng 七政 refers to. 
of the Way grew forth from innate knowledge and her spiritual demeanor came forth from her Heaven-sent nature. Clean of all falsity and pure on the inside, she studied and taught the arcane gate. She left home at seventeen and her practice of the precepts was clear and pure. When she reached the age of twenty, her moral virtue was rich and profound. By abiding in concentration, she had arrived at the six supernormal powers ${ }^{20}$ and so could serenely recite many [sütras] after hearing them one time. She chanted more than twenty scrolls of sütras, including the Nirvanna Sütra, ${ }^{21}$ the Lotus Sütra, ${ }^{22}$ the Srimālà Sütra, ${ }^{23}$ and thus, the great assembly recommended her to lecture on the sütras. With a single exposition in the Dharma-master's elegant prosody, those who admired her righteousness [amassed] like clouds; with a fleeting chant in her marvelous voice, those who took refuge in the Way were [thick] like a forest. ${ }^{24}$ Thus, she could shake the Yellow and the Wei Rivers with her voice, and reach both the Qi and the Liang mountains with her virtue. ${ }^{25}$ This was in the beginning of the Taihe era (477-499 CE). 崇訓皇太后之姑, 禀三才之正氣, 含七政之淑靈. 道識發於生知, 神 情出於天性, 洗/耶素里, 習教玄門. 十七出家, 戒行清純, 暨於廿, 德義淵

The Book of History (Shangshu 尚書) identifies a group of astral constellations as the governances, and yet in the Annals of the Historian, the governances are given as heaven, earth, man, and the four seasons. In any case, the usage is the same as in the 'Three Capabilities' above in that the ascription of them to Sengzhi is for the purpose of showing the nun's virtue, a virtue endowed by the cosmos itself and acted out in society.

20 This is a Buddhist term signifying the powers that a highly advanced being on the path to Buddhahood has attained through their practice and includes such capabilities as a divine eye. Sengzhi's advanced practice of meditation have been thought to have placed her on this path.

21 A reference to the Nirvāna-sūtra (T no. 374: Da boniepan jing 大般涅槃經).

22 A reference to the Lotus Sūtra (T no. 262: Miaofa lianbua jing 妙法蓮華經).

23 A reference to the Shengman shizi hou yisheng da fangbian fangguang jing 勝鬢師子吼一乘大方便方廣經 [Sūtra of Queen Śrīmālā of the Lion's Roar; Skt. *Śrimālādevī-siṃha-nāda-sūtra; T no. 353].

24 Both 'like clouds' and 'like a forest' are poetic ways of saying that there were many of them.

25 These are two mountains in modern-day Shaanxi province. 
富. 安禪届於六通, 靜讀幾於/一聞. 誦《湟槃》《法華》《勝鬘》廿餘卷, 乃為大眾所推講經. 法師雅韻一敷, 慕義者如雲; 妙音磛唱, 歸道者如林. 故能聲動河渭, 德被岐梁者矣. 以太和之初.

Empress Dowager Wenming was in the imperial city ${ }^{26}$ determined to transcend worldly custom. Greatly admiring [Sengzhi's] mastery and venerating her manner and intent, she consequently commanded the postal carriage to immediately and officially summon Sengzhi. When [Sengzhi] arrived at the capital, she was venerated with extraordinary protocols. 文明 太皇太后聖鏡城中, 志超俗表, 傾服徽猷, 欽崇風旨, 爰命驛車, 應時徵辟. 及至/京都, 敬以殊禮. /

Gaozu, Emperor Xiaowen, whose path brought abundance to heaven and earth, and whose brilliance exceeded the sun and the moon, poured all of his sincerity into his receptions [with Sengzhi] [such that] the matter transcended the ordinary principle of human relationships. 高祖孝文皇帝 道隆天地, 明踰日月, 傾誠待遇, 事絕常倫. /

Shizong, Emperor Xuanwu entrusted his heart to the three treasures, bestowed more and more favors on her, and lead her into the women's quarters to instruct the six palaces. ${ }^{27}$ 世宗宣武皇帝信心三寶, 弥加弥寵, 引 內闈掖, 導訓六官. /

The Emperor ${ }^{28}$ ascended the throne. 皇上登極/

26 Here, I am following a reference in the Book of the Wei in translating 聖 鏡 as a metaphorical reference to the Emperor: 祚對日, ‘陛下聖鏡照臨, 論才授 職，進退可否，黜陟幽明，品物既彰，人倫有序，豈容聖詔一行而有差異.' (Wei shu 64:1422). As such, I am rendering 聖鏡城 as imperial city, which makes sense given Empress Dowager Feng's location as ruling monarch. The term also shows up in the eulogy of the muzhiming of Northern Wei general Wen Yuan 元文 (d. 532), who died as a nine-year old. Here it is again used metaphorically, though in reference to the child. The inscription can be found at: http://kanji. zinbun.kyoto-u.ac.jp/db-machine/imgv/takuhon/type_a/html/nan0358x.html (c.f., Zhao, comp., Han Wei Nanbeichao muzhi huibian, 297). Alternatively, 聖 鏡 could potentially be understood for the homophone 聖境, but I do not think that that is the case here.

27 The six palaces refer to the bedchambers of the King's principal wives (Hucker, Dictionary, 318). Hence, Sengzhi was put in charge of all the matters of the women's court. 
When Empress Dowager Ling held court, she honoured her kinsfolk and favored them, and [so] respect for [Sengzhi's] name was more than doubled. And yet the Dharma Master's expanse of inborn humility was such that not even 1,000 ren ${ }^{29}$ could measure its height and the capacity for cultivation in her heart was such that not even 10,000 kui could compare to its width. ${ }^{30}$ 皇太后臨朝, 尊親属既隆, 名義之敬踰重, 而法師謙虛在己, 千 仞不測其高, 容養/為心, 万頃無擬其廣. /

Empress Dowager Feng 馮 of Xiaowen 孝文 ${ }^{31}$ and Empress Gao 高 of $\mathrm{Xuanwu}^{32}$ and more than twenty wives and concubines-even Madam Xie, the wife of the former General of the Carriages and Horses and the Minister of Works, Wang Su 王肅 ${ }^{33}$ who was herself the daughter of The Great minster of the Glowing Blessing of the Office of Fasting of the Right and

28 This is a reference to the current reigning emperor at the time of Sengzhi's death, the then six-year-old Emperor Xiaoming 孝明 (r. 516-528 CE).

29 Ren 仞 is a unit of measure equal to about eight feet.

$30 \mathrm{Kui}$ 頃 is a unit of measure equal to 100 mou 畧, or 1.5 acres.

31 This is a reference to Emperor Xiaowu's first empress from the Feng clan, Feng Qing, who also would have been living at the nunnery of the Northern Wei court.

32 This is a reference to Emperor Xuanwu's official Empress Gao who, by this time, would have been a widow living at the imperial nunnery of the Northern Wei court.

33 Wang $\mathrm{Su}$ is mentioned in many places in the Book of the Wei, with connections to Emperors Xiaowen and Xuanwu; however, he does not appear to have his own biography in the Book of the Wei. Originally from Shandong, he became a minister at the Northern Wei court. The Record of Buddhist Monasteries in Luoyang (Luoyang qielan ji 洛陽伽藍記) records that he built a nunnery for his first wife, Madam Xie. According to the text, Madam Xie was Wang Su's first wife who was replaced and dejected when Wang Su came north to take a position in the Northern Wei and marry a Tuoba Princess. Much to Wang Su's embarrassment, the text says, the two women engaged in a public poetry battle over their shared man, and this resulted in Wang Su building the nunnery for his first wife to live out her days in. The story of the nunnery and the poetry battle as well as a lengthy description of Wang Su's habits are all detailed in Luoyang qielan ji, T no. 2092: 1011b09-c20. 
The Secretariat of the History Section, [Xie] Zhuang 莊 (d.u.) who came from Jinling ${ }^{34}$ - sought refuge in the seclusion of the imperial palace. ${ }^{35}$ Considering the way of the Dharma Master to crown the universe, and her virtue to be commensurate with the creation of things, [the women] therefore cast aside their extravagant customs, clothed their bosoms in the gate of the teaching, and all became disciples of the Dharma Master. From all of these nuns so cloaked in their integrity, those who rose up in rank and those who took the high seat were too many to record. When [Sengzhi] had reached seventy-five years, in the first year of the Xiping era (516), which was a bingjia year, during the first month, on a bingwu day nineteen days after the new moon, which was a wuchen day (March 7, $516 \mathrm{CE}$ ), she came to the end of her life in the Nunnery of the Le'an Princess. ${ }^{36}$ The Emperor was overcome with grief and the clergy and the laity were bound together in mourning. Then, on the twenty-fourth day of the month, a xinmao day (March 12, $516 \mathrm{CE}$ ), they buried her north of Luoyang on the south slope of Mount Mang. Her great disciples, the bhikșnīis, duweinas, ${ }^{37}$ and

34 Jinling is a reference to modern day Nanjing 南京, which would have been the capital of the Southern dynasty, the Liang (502-557 CE), during the time in question. This region had long been important for the development of Buddhism in China, particularly for women, as it was the court of the Liu Song (420-479 CE), whose capital was also in Jiankang, which first sponsored full canonical ordination for Buddhist women. Madame Xie, the wife of Wang Su, was herself a southerner from Jinling who may have known of Sengzhi from the South prior to coming to the North. Wang Su's wife was a member of the southern elite and her father had held positions of influence at the court of the Liu Song.

35 The only Buddhist building to be built inside the palace walls of the Northern Wei palace in Luoyang was the Yaoguang 瑤光 nunnery, which the Luoyang qielan ji states was for the express use of court widows (T no. 2092: 1003a01-a28). I suspect that it is to this nunnery that the women of the court frequented, doing so under the leadership of the nunneries most prestigious residents: the widowed Empress Gao and the widowed Empress Feng.

36 We know little about the Le'an Princess other than that she was an orphaned daughter of Emperor Xianwen and sibling of the then child Emperor Xiaowen. It is likely that Sengzhi was her caregiver at court and that, if so, the Princess repaid Sengzhi's kindnesses by lodging her at her personally sponsored nunnery. 
Dharma Masters, Senghe 僧和 and Daohe 道和, mourning the long-dimming of [her] numinous shadow and yearning for the eternal cover of [her] divine authority, wailed [for her] until they lost their voices, and ceremonially spoke about [her] fragrant merit. Though hills have changed to valleys, [her] great goodness will never dim. The eulogy said: 孝文馮皇后, 宣武高太后逮諸夫嬪廿許人, 及故車騎將軍, 尚書令, 司空公王肅/之夫人 謝氏, 乃是齋右光禄大夫, 吏部尚書㽵之女, 越自金陵, 歸蔭天關. 以法師 道/冠宇宙, 德兼造物, 故捐拾 (=捨) 華俗, 服胸法門, 皆為法師弟子. 自餘 諸比丘尼服義而昇/高座者不可勝紀. 春秋七十有五, 熙平元年嵗次丙申 正月戊晨朔十九日丙戊夜/分, 終於樂安公主寺. 哀慟聖衷, 痛結緇素, 其 月廿四日辛卯, 遷䆘於洛陽北芒山/之陽. 大弟子比丘尼都維那法師僧和, 道和, 痛靈蔭之長伹, 戀神儀之永毉, 號慕餘/喘, 式述芳猷. 若陵谷有遷, 至善無昧. 乃作銘日：

Her prajña was without origin,

The essence of her soul was without measure.

Her ripe discourses reached the Way,

From whence was her mastery.

Lo, that one of supreme benevolence,

Filled with attainments to the utmost!

Wholeheartedly she entered into purity

Cleansing her wisdom, she melted all material forms.
般若無源

神理不測

熟詮至道

爰在妙識

猗興上仁

充榛窴極

凝心入淨

晹智融色 /。 [6ik]

$\left[\mathrm{ts}^{\mathrm{hik}}\right.$ ]

[gik]

$[$ sik]

37 According to Jonathan Silk, although the origin of the term weina is something of a mystery, the words are likely aligned with the Sanskrit karmadāna. In his study, Silk shows how the weinuo were involved in the intricate day-to-day running of the monastery, including locking the gates at night and keeping time. He also presents evidence that the appointment of a weina was to come from the monastic community and not from the laity (Silk, Managing Monks, 127ff). In her review of Silk, Kieffer-Pulz has also commented on the meaning of the word karmadana, and though she understands it differently, she still relates it to the task of administering the monastery (Kieffer-Pulz, 'Review', 80). In reference to the women leading Sengzhi's funeral, they were weinuo of a metropolitan area, or duweina. 
Turning the wheel of the three existences, 輪轉三有

She completely manifested the six supernatural powers. ${ }^{38}$ 周流六通

[ $\mathrm{t}^{\mathrm{h}}$ วwy]

Individual goodness is not virtue;

獨善非德

[and so] she also made merit from saving [others].

兼濟為功

[kəwy]

The serene water-mirror [of her mind] quietly extinguished her arcane awakening was like emptiness.

Harbouring that bright expanse,

幽鏡寂滅

She fell into this dust-laden [world].

玄悟若空

$\left[\mathrm{k}^{\mathrm{h}}\right.$ วwy $]$

懷彼昭曠

落此塵封/

[puawn]

With clear insight in all directions,

洞鑒方等

She deeply embraced the Basket of the Conduct. ${ }^{39}$

深苍律藏

[dzay]

Her subtle words have now ended

微言斯究

but their profound meanings all flourish.

奥旨咸㭡

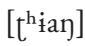

As soon as she ascended the treasured seat,

寶座既昇

Did her dharma voice sing,

法音既唱

[chian]

Converting heterodox views to orthodox ones,

邪40觀反正

And blocking the spread of spurious teachings.

異旨輟障 ${ }^{41}$

[cian]

Her virtue was heavy, and her teachings were honoured，德重教尊

Her behaviour was profound, and her prestige was long lasting. 行深敬久

$[\mathrm{kuw}]$

She bequeathed proper etiquette to three emperors, ${ }^{42}$

貽禮三帝

And welcomed [the chance] to care for two empresses. ${ }^{43}$

迎頋二后

[həw]

38 My reading here disagrees with Wang's: whereas Wang has 道, I have 通. This emendation is based on three factors: 1) the rhyme; 2) a re-examination of the rubbing of the epigraph which does appear to read as 通 when compared to other examples of 道 on the epigraph; 3) popular Buddhist usage of the six supernatural powers (liutong 六通) from the time period.

39 A reference to the Vinaya-Pitaka, the canons of Buddhist law.

40 Wang Shan's texts corrects 耶 to 邪.

41 Corrected from 鄣.

42 This is a reference to Emperors Xianwen, Xiaowen, and Xuanwu, whom Sengzhi would have had a direct hand in raising. 
By means of truth, she returned to things,

物以實歸

By means of emptiness, she approached the self.

我以虛受

[dzuw]

Just as the East gives rise to the ruomu tree,

東發若木

And the West brings forth the delicate willow.

西迫細柳/

[luw]

Her strength and behavior never wearied

力行不倦

Although new and old are mutually at odds.

新故相違

[huj]

Impermanence is nothing other than transformation,

無常即化

And so, world-weary, she returned to the pivot.

厭世還機

[kij]

The lamp wick of her wisdom burns concealed:

慧炷潜耀

What can we rely on to reach our Elder?

攀宗曷依

[?ij]

In yearning, monastic and lay are bound together,

慕結緇素

Lamenting and mourning for her care.

嗟䡃/聖慈

[dzi]

Her spirit travels to the pure city

神遊淨城

While her body is interred on the lofty [Mount] Mang;

體袝崇芒

With its dark passes, its deep serenity,

幽關深寂

And its old mounds, wild and cool,

宿隴荒凉

[liay]

[There] cinnabar ravines are linked together

丹餐且連 ${ }^{44}$

And the dragon flowers ${ }^{45}$ never end.

龍花未央

[?ian]

With these mere notices in this black stone,

聊誌玄石

we sound out our yearning for her lingering fragrance,

試慕/餘芳

[p $\mathrm{p}^{\mathrm{h}}$ uan]

43 It is difficult to conjecture exactly which empresses these two would be, but I suspect that this is a reference to the two ruling empresses that bookended the life of Sengzhi: Empress Dowager Wenming who brought her to court, and Empress Dowager Ling who Sengzhi brought to court.

44 My reading, here, disagrees with Wang's transcription, who records this as 遊; however, given the rhyme, a re-examination of this character was necessary and indeed the rubbing of the epigraph could appear to be read as 連, as I have it here.

45 Mesuna Ferrea, the tree under which Maitreya will attain Buddhahood. 
[In order to] cultivate and disseminate her Way in the world.

The fragrance of flowers fills all four directions,

and the Nirvana Carriage ${ }^{46}$ is high and lofty.

Both monastic and lay are overcome with melancholy:

Brahma-sounds enter the clouds

修播界道

馚花四盈

[jiaj)]

洹舉俄俄

真俗悲傾

[k $\mathrm{k}^{\mathrm{h}}$ wiajp]

梵鄉入雲

As do mournful and sour dirges.

哀感酸聲

[6iaj门]

Her disciples weep and wail as they take part in the procession,

眾子號咷而奉/送

calling themselves poor orphans and lonely rejects.

稱孤窮而單營照wiaj门]

The mountains and rivers have lost their lustre for her,

山水為之改色

Spring has stirred the grasses, yet there is no thriving.

陽春觸草而不［hwiaj门]

Oh! She is gone.

哀哉往也

[jia]

Such sadness! There is no return.

痛矣無還

[zwian]

46 This translation is conjectural and based on both context and contemporaneous usage. The characters themselves (buanyu 洹轝) make little sense together except when we consider that 洹 is perhaps an abbreviation for nibuan 泥洹, an early transliteration of the Sanskrit 'nirvana'. If we can accept that this might be the case, then we can find further support for the translation of 'Nirvana Carriage' in the Book of the Southern Qi, or Nanqi shu 南齊書, which in the biography of Liu Biao 劉彪 (d.u.) tells of a nibuanyu 泥洹輿 (our $y u$ 舉 and this $y u$ 輿 are variants), which was used in funerary practice to transport one to their tomb. Furthermore, the Biographies of the Tripitaka Masters from the Great Ci'en Monastery in the Great Tang ( Da Tang Da Ci'en si sanzang fashi zhuan 大唐大慈恩 寺三藏法師傳; $T$ no. 2053) tells of a similar funerary carriage, also a nibuanyu. Finally, though less closely related, the Tang dynasty, A Record of Personal Memos on Textual Explanation of the Marvelous Scripture (Miaojing wenju sizhi $j i$ 妙經文句私志記; $X$ no. 596) refers to a similar Nirvana Carriage as a niepanche 涅槃車. 


\section{Discussion: Situating Sengzhi as a Court Servant}

From the translation and introduction above, we know that Sengzhi had a quite different life than that of her contemporaries in religion entombed at Mount Mang. Unmarried and virtuous, Sengzhi stands as the earliest dated example we have on record of a virtuoso Buddhist nun in East Asia. Disconnected from men of rank and not relying on the sexual politics of the harem for her own status at court, Sengzhi's life story shows us for certain that at least one real-life woman in early medieval China was able to signal social prestige through Buddhist markers of attainment and how, relatedly, she was able to live life as a virtuous woman disconnected from the patrilineal family, which was the basic unit of social organization in medieval times. Somewhat counter-intuitively, however, her disconnection from the patrilineal family allowed her to serve the imperial clan and its affines; not planning to marry any of them, she was trusted to manage their lives. This is not the case for the other Northern Wei nuns whom we have entombed biographies for, and it should therefore be no surprise that Sengzhi held rank over them even though they were royalty and she was not.

Though like her contemporaries, the verbal act of becoming a nun as described in her biography uses language of 'leaving home', the biography makes it clear that the circumstances of her renunciation were unlike theirs. The text tells us that her renunciation came as a natural inclination from her own inborn religious qualities and not-as in the other cases mentioned above-as a result of her widowhood. Moreover, further different from the other women entombed at Mount Mang, Sengzhi’s biography gives ample discussion of what having left home meant for her. Not only does it state that she 'left home', but it follows this up by telling the reader, in Buddhist language, that her 'practice of the precepts was clear and pure' and that 'she deeply embraced the Basket of the Conduct'language which might suggest that she was legally ordained. This is an important distinction because, as is well known, the project of establishing canonical precept ordination for women in China was not an easy one, ${ }^{47}$ and we have clear evidence of women living as nuns without any mention to them practicing the precepts, such 
as in the case of Ciqing and Ciyi above. Furthermore, in looking for differences between her status and that of her contemporary's, Sengzhi's own religious name is rare among those of other Buddhist women of her time from the North of China, where we in fact have no evidence whatsoever of legal ordinations for women being undertaken. Containing three characters and not two, and with the first character, $S h i$ 釋, signifying a belonging to the family of the Buddha Śākyamuni, Sengzhi's very name suggests that, perhaps, her status as a nun reflected her belonging to a community outside of the confines of the imperial nuns of the Northern Wei court. The only other reference to $S h i$ as a religious name that I have found among individuals at the Northern Wei court is from the entombed biography of a high-ranking male monastic and political figure. His biography clearly states that upon ordination, he 'deposited his heart in the clan of Shi ${ }^{48}$ Like Sengzhi, this particular monk carried important titles that gave him influence both at court and in the monastery. Given the similarities between their status at the Northern Wei court, the time frame in which they served that court, their burials at Mount Mang, and their shared religious name, we might assume that these two individuals belonged to a religious community that signaled prestigious and virtuosi practice to Northern Wei courtiers and religious practitioners. Perhaps this community was one that underwent legal and canonical ordination. Indeed, we know from later sources that $S h i$ was-and remains - a common dharma name for legally ordained monastics, male and female.

However, if Sengzhi acquired legal rank as a Buddhist nun which set her apart from the other imperial nuns of the Northern Wei and

\footnotetext{
47 Heirman, 'Chinese Nuns', 275-304.
}

48 This is from the entombed biography of the Northern Wei Dharma Master Sengling and Great Superintendent of the Śramanas, who Clarifies Profundities (Wei gu Zhaoxuan shamen Datong Sengling fashi muzhiming 魏故昭玄沙門大 統僧令法師墓誌銘). The entombed biography is currently in the Shaanxi Provincial Museum and a transcription of the biography is available online from the Chinese Buddhist Electronic Text Association (CBETA) at: http://cbetaonline. dila.edu.tw/zh/I0032_001. 
allowed her to be their superior, how did she acquire that rank? In Sengzhi's own lifetime, full, canonical, precept ordination for women was just starting to be practiced in China, though only in the South. The first legal and canonical ordinations for women in China happened in 433 of the Common Era and with the support of the court of the Liu-Song, ${ }^{49}$ which both helped to bring a requisite quorum of already-ordained Sinhalese nuns to the region as well as supported the translation of the Dharmaguptaka-vinaya (Sifen lü 四 分律) under which the new Chinese nuns were ordained. According to her biography, Sengzhi 'left home' at the age of seventeen, which would have been in 458 of the Common Era, ${ }^{50}$ and she subsequently came into the employ of the Northern Wei court in $477 \mathrm{CE}$, already an eminent nun. It is doubtful that if Sengzhi was ordained, she was ordained in the North. What little evidence we have attesting to the practice of monastic ordination for women in the Northern Wei suggests a clear lack of understanding of the requisites for ordination. For example, if we return to the story of Zhishou above, the title by which she is known on her entombed biography reveals that she, or those who wrote about her, misunderstood the very title that she held. A princess from the Tuoba family, Zhishou's title retains the Tuoba's sinified family name, Yuan 元; however, it does so in quite an odd configuration, labeling her a biqiuyuanni 比丘元尼. Her title has therefore been constructed with the family name of the royal house implanted directly into the middle of a three-character singular semantic unit: the Chinese transliteration of the Sanskrit

49 The story of this first full ordination in 433 is found in the Lives of the Nuns (Biqiuni zhuan 比丘尼傳) in the biography of the nun Huiguo 慧果 (364433), who was a leading pioneer in the struggle ( $T$ no. 2063: 937b18-c7).

50 This date has been approached because of internal evidence in the biography which states that she died in $516 \mathrm{CE}$ at the age of seventy-five, which would put her birth in $441 \mathrm{CE}$ and her ordination, then, in $458 \mathrm{CE}$ as the biography says that she was seventeen when ordained. Though we have no way of verifying this date of birth, we do know that her elder brother, Hu Guozhen, is supposed to have been born in $438 \mathrm{CE}$, which would make sense with the dates in her own lifetime. 
bhiksunī. From such a strange placement of the family name, we might conclude that this princess of the Tuoba house-or those who knew her by this title-did not have a clear grasp of what the underlying Sanskrit term meant or how to use it. In understanding this bizarre rendering, it might make sense to consider the $n i$ 尼 for its homophone, ni 妮, meaning 'young lady' or 'maiden'. In this way, the biqiuyuanni would not be translated as a broken up transliterated term interspersed with a family name, but, rather, as 'The biqiu lady of the Yuan family', wherein biqiu itself is retained as a complete semantic unit designating the foreign concept of monasticism in its foreign language. This interpretation of the title is conjectural; however, it finds resonance with similarly intriguing naming practices seen in contemporaneous inscriptions. ${ }^{51}$ Whatever the case may be,

51 For example, in the Northern Wei Yao Boduo 姚伯多 stele of 496, which Stephen Bokenkamp has studied for its syncretic Buddho-Daoist imagery and text (Bokenkamp, 'Yao Boduo Stele', 55-67), we see the Buddhist-inflected names and titles of a number of women, who are all listed as being of 'Pure Faith' (qingxin 清信). The designation of 'Pure Faith' is generally seen as a translation of the Sanskrit, upāsaka/upasikēa, generally taken to designate a lay member of the Buddhist community. In donor inscriptions, the designation 'Pure Faith' is generally followed by a third character that would complete the gendered nature of the Sanskrit term, so in Chinese, this is normally shi士 for a male and nü 女 for a woman, making the terms as such: qingxinshi 清信士 and qingxinnü 清信 女. However, in the Yao Boduo stele the titles are differently given and provide context, perhaps, for the biqiuyuanni. Listed among the donors of that stele are five women, given as such: two unmarried women from the Hu clan who contributed to the donation of an image as lay patrons, or 'Women of Pure Faith' (qingxinnü): 1) Hu Nüjin of Pure Faith who Gives Offerings (qingxin Hu Nüjin gongyang 清信胡女進供養); 2) Hu Mienü of Pure Faith who Gives Offerings (qingxin Hu Mienü gongyang 清信胡策女供養); 3) Liang Dongji of Pure Faith who Gives Offerings (qingxin Liang Dongji gongyang 清信梁冬姬供養); 4) Niu Jiang of Pure Faith Who Gives Offerings (qingxin Niu Jiang gongyang 清信牛 姜供養); 5) Wang Zangnü of Pure Faith Who Gives Offerings (qingxin Wang Zangnü gongyang 清信王藏女供養). These titles all drop the gender signifier that would complete the term translated from Sanskrit because the names of 
it is clear that the title of bhikșuni was misunderstood as applied to the Tuoba princess. Such a fact calls into question the veracity of her legal claim to the title for it is unlikely that a requisite quorum of already-ordained bhikșunis would support the ordination with a wrongly-applied monastic title. Furthermore, one additional shred of evidence suggesting that the North did not understand the complications of legal and canonical ordination for Buddhist women comes from the Book of the Wei's 'Annals on Buddhism and Daoism' where, on the topic of female renunciation, the text does not reference the differing levels of ordination that exist for female novices and simply records that nuns have 500 rules, some of which are in addition to those of men. ${ }^{52}$ Moreover, the Book of the Weis brief description of female ordination does not included mention of the complicated process for their legal ordination, which includes quorums of both already-ordained men and women, the latter of which was a major problem for the Liu-Song and their ordinations because there were no already-ordained nuns in China.

All of the above is to suggest that if Sengzhi was ordained, she was not ordained in the North. But, can we place her in the South? The biography tells us that it was due to her reputation for chanting Buddhist sutras that Sengzhi earned renown as a nun and was thereby summoned to court service by Empress Dowager Wenming. The North has never been a producer of Buddhist textual translations or writings in the way that the South has been, and, in fact, the very sütras that Sengzhi was famed for chanting connect her with those famed translation bureaus of the South. Specifically, her biography provides the earliest epigraphic attestation to a sütra that features

the women in question all have characters that signify their gender. What this shows is that, in the period, there was both flexibility in how to create a title and, perhaps, different understandings (and misunderstandings in the case of grammatical gender) of what such new and exotic titles mean in their medieval Chinese context. An image of the stele is available, see Beijing Tushuguan Jinshizu, Taben, 3.26-8.

52 Wei shu 114: 3026-7; on the topic, see: Balkwill, 'When Renunciation is Good Politics', 231-2. 
court women as learned teachers of the dharma, the Srimālādevi Sütra, ${ }^{53}$ which is recorded to have been translated into Chinese during the Liu-Song by the monk Gunabhadra 求那跋陀 in the year 436 of the Common Era-some twenty years prior to Sengzhi's own ordination. It is also elsewhere recorded that the text was preached hundreds of times during the Liu-Song to audiences of more than a thousand. ${ }^{54}$ If Sengzhi journeyed to the Liu-Song to receive ordination from the only established community of legally ordained nuns in China in her life time, she would have been in those audiences at the Liu-Song court and learned of the Śrimālàdevi Sütra there. Her ability to peerlessly chant this new and increasingly fashionable text-a text that highlights the Buddhist practice and expertise of powerful court women-would certainly have been of interest to her first benefactor at the Northern Wei court, the Empress Dowager Wenming, who, at least publicly, was a fervent Buddhist and who ruled the dynasty from behind a succession of two child emperors while pushing the court and the public toward increasing Buddhification and Sinification. Relatedly, the Śrimālādevi Sütra also became fashionable at the court of another East Asian female ruler, that of Empress Suiko 推古天皇 (r. 593-628 CE) of Japan who ruled about a century after the life of Sengzhi. Famously, the Empress's semi-mythical regent, Prince Shōtoku 聖徳太子 (574-622 $\mathrm{CE})$ is believed to have written a commentary on the sütra and prided it as one of the three most important in circulation at his time. ${ }^{55}$ Given the Northern Wei's connections to the late Yamato

53 I have yet to see other mentions of this text in Northern materials outside of Sengzhi's entombed biography. Otherwise, the earliest attested inscriptional evidence for the sütra seems to be from the Northern Qi 北齊 (550-577 CE) and, as far as I am aware, comes from the Xiao Nanhai 小南海 caves in Henan which were carved in the 550s (on which, see Kuramoto, 'Koku kyō kara mita gyō no bukkyō').

54 Wayman, Lion's Roar, 12.

55 Rather notably, the other two texts in this grouping, the Sütra of the Lotus of the Wonderful Dharma (T no. 262: Miaofa lianbua jing 妙法蓮華經) and the Vimalakirtinirdeśa Sūtra (T no. 425: Weimojie suoshuo jing 維摩詰所說經) also 
court—both Buddhist and political—Sengzhi's entombed biography may be rare, dated evidence for the early transmission of the text from China to Japan via the northern route through Korea.

Sengzhi's biography is different enough from those of her contemporary's in the North that we can reasonably assume that she was a different sort of woman, a different sort of nun. Perhaps she was a legally ordained Buddhist woman who received canonical ordination in the South before traveling to the North and being called to the Northern Wei court. If we are to trust the historical information contained in the canonical biographies of early Buddhist monastic women, the Lives of the Nuns (Biqiuni zhuan 比丘尼傳), we see that a number of the early nuns are recorded to have been ordained in the Liu-Song were not women of the South. Without explanation, we are told many times in those biographies that the women in question came from far-away places across the empire, and so, it is not unreasonable to think that Sengzhi was one among them. Furthermore, the honours and titles that she was given while in the service of the Northern Wei court befit a woman of such anomalous prestige in her time. Other than being a nun, Sengzhi held important positions of influence at both the Northern Wei and in the Northern Wei's monastic institutions. First, from above we know that Emperor Xuanwu tasked her with the responsibility of leading the administration and management of the women's chambers of the court. Because the political statuses and the very lives of the women who filled the inner chambers was entirely dependent on their ability to maintain close connections with imperial men, this sector of the court was constantly plagued by competition and gendered forms of political violence. Sengzhi, a perhaps legally ordained nun who would have been thought to follow a set of rules that strictly forbade marriage and sexual activity, was not in sexual competition with the women around her. As such, she was the ideal candidate to be their leader. Similarly, her ability to lead the women of the court extended

contain stories of strong female protagonists which have has a lasting impact on the development of Buddhism in East Asia, particularly on the roles of women in the tradition. 
to the nunnery where imperial women, as a result of either their widowhood or general loss of favor at court, spent large portions of their lives. In the nunnery, they would have been under the legal command of Sengzhi because she was the 'Superintendent of the Nuns'-an important position at the Northern Wei court which allowed for the facilitation of the court's policies on religion to be transmitted to and enforced in the Buddhist monastic institution.

In sum, what we see in Sengzhi's biography is that she was arguably a legally ordained Buddhist nun who was brought to the Northern Wei court to act as a virtuoso Buddhist who held the ability to manage the ranks of women at court because she was trusted not to be in competition with them. In so doing, it appears that she oversaw something like a religious network for lost and/or deposed court women, whether they wanted to be in that network or not. The biography provides the names of three particularly noteworthy women in this network, all of whom suffered nuptial upheavals that forced them to the nunnery. As for the first two, Empresses Gao and Feng share a similar fate: as official partners of successive emperors, Xiaowen and Xuanwu, Gao and Feng had to have been the two most eminent women in Sengzhi's care. As for Gao, otherwise known as the aforementioned nun, Ciyi, she relocated to the nunnery after the death of Emperor Xuanwu and after attempting to murder Empress Dowager Ling, who then eventually murdered her. As for Empress Feng, her own career at court was dramatically and negatively affected by her own aunt, the Empress Dowager Wenming. Fearing that she may lose control over Xiaowen because of his love for the young Feng, Empress Dowager Wenming banished her niece to the nunnery. ${ }^{56}$ After Wenming's death, the niece came back to court to resume her status at the side of the Emperor. Her arrival at court, however, caused the banishment of her own sister who was herself married to the Emperor in the other sister's stead. That sister, Emperor Xiaowen's first Empress, went to the nunnery in shame

\footnotetext{
56 All of these details regarding the lives of the Feng sister-empresses can be found in their back-to-back biographies in the Book of the Wei (Wei shu 13: 332-5) and are the subject of Balkwill, 'When Renunciation is Good Politics'.
} 
when her sister returned to court and resumed her status as the Emperor's favourite. Though the Empress Feng mentioned in this text could in fact be either of the sister empresses, I suspect that the Empress in question is the favored sister as she is generally better treated in their biographies in the Book of the Wei and would have been the one to be mentioned alongside Empress Gao. Finally, as we have seen, the biography also makes mention of a certain Madam Xie, wife of Wang Su. Though not an empress, Xie shared a similar fate. Xie was a southerner whose father held important positions at the court of the Southern Liang 南梁 (502-557 CE). Xie was married to Wang when he served in the South; however, Wang was later persuaded by political position to relocate North and to work for the Northern Wei, a position that included marriage to a Tuoba princess. Xie, however, did not take her dejection and abandonment lightly. ${ }^{57}$ Journeying to the North herself, Xie engaged in a public poetry battle with her husband's new wife over her status viz-a-viz their shared husband. This public shaming of Wang provoked him to do right by Xie by building her an opulent Buddhist nunnery where she could live out her days in luxury but, also, presumed sexual abstinence. Along with Empresses Gao and Feng, the biography tells us that Madam Xie became one of Sengzhi's most eminent disciples in the Buddhist network of Northern Wei women. Whether or not these three women believed in Buddhism and were actually inspired by Sengzhi's virtuous practice is irrelevant to their situation as eminent members of her congregation. What they gained from Sengzhi's care is not enlightenment or other-worldly salvation, but rather the opportunity to reestablish their connections in this world after having lost the primary means by which they first gained them-their men.

And so, it is in this realization of who filled Sengzhi's congregation and who benefitted by the existence of this imperial Buddhist women's network that we gain some insight into how Sengzhi managed to hold the role that she did. Sengzhi held a very difficult position. As assistant to the very powerful Empress Dowager Wenming, she

57 This story can be found in the description of the Perfect Enlightenment Nunnery (Zhengjue si 正覺寺) in the Luoyang qielan ji, T no. 2092: 1011b9-c20. 
would have been at her side during the struggle for Emperor Xiaowen's attentions that ensued between the Empress Dowager and the two Feng Empresses, her nieces. Similarly, she would have been deeply involved in the career and advancement of her own niece who she herself appointed at court and who then went on to birth a son by the Emperor and then ascend to her dowager regency by murdering her competition-Empress Gao, the nun Ciyi, who was in Sengzhi's care. Sengzhi died and her entombed biography was written between the commencement of Empress Dowager Ling's regency and the death of Empress Gao, which would have been the most dangerous two years in the latter's life. The fact that she is enumerated by name alongside Empress Feng is therefore intentionally political for neither of these women are likely to have been very close to Sengzhi. Sengzhi was the direct beneficiary of both of their enemies, even though these two women were likely the highest-ranking nuns in her care. Appointed by Empress Dowager Wenming, Sengzhi was probably not well liked by Empress Feng who was severely mistreated by the Empress Dowager as a result of her closeness to Emperor Xiaowen. Similarly, having herself appointed Empress Gao's competition and eventual murderer to court-the Empress Dowager Ling-Empress Gao had every reason to fear Sengzhi's political power and alliances. Sengzhi, therefore, was not a friend to these women; however, she was their superior. In a Buddhist network of both monastic and lay women of the imperial elite, Sengzhi was the highest-ranking officer and, in this role, served the highest women of the realm: Empress Dowagers Wenming and Ling. In a managerial position that both provided and administered community to deposed and discarded women of the imperial elite, Sengzhi was the head of an institution that had the ability to separate those women from the court and therefore keep them out of the path of her benefactors, the Empress Dowagers. This was an incredibly powerful position and it may even be possible that, at the height of her power as Emperor Xuanwu's favored teacher of the dharma, she was aware of a vacuum in female leadership created by the death of Wenming in 490 of the Common Era and thereupon seized the opportunity to promote her own niece to court who then birthed a son by Xuanwu in 510 . 


\section{Conclusion: Why Sengzhi Matters}

An appropriate concluding question to this study which sought to situate the nun Sengzhi in her own social and religious milieu might be: Why did she have the power that she had? Outside of the lowly ranks of the menial service, it is rare to see an unmarried woman serving the court. Indeed, a woman disconnected from imperial marriage, motherhood, or sexual relations is not normally regarded as a woman of virtue. This gender paradigm is no different in the Tuoba culture of the Northern Wei than it was in the Han Chinese culture of the South. Across both realms and before Sengzhi's time, we do not have evidence that such political office for unmarried women at court existed. And yet, in Sengzhi's entombed biography we see it to be the case. Why? What made her so rare? What made her so appropriate for the position that she held?

One answer, simply, is Buddhism. Unlike the other women of the court, Sengzhi did not turn to Buddhist monastic life as a result of court intrigues; rather, she was brought to court because of her Buddhist practice, rank, and reputation. A woman who marked her social prestige through Buddhist notions of virtuosi practicemeditation, chanting, teaching, obeying of the precepts-Sengzhi's public virtue was of a markedly different sort than that of any of the other women around her. Her virtue drew not from her relationship to the patrilineal family unit, but, in fact, from her distance from it. To be certain, the type of womanhood that Sengzhi manifested in her time was entirely new. China never knew of religious renunciation prior to the arrival of Buddhism and, in fact, never had a tradition of lone, female religious wanderers, as it did for men. Given that if Sengzhi was legally ordained into Buddhist monastic life, her ordination was undertaken only a mere few years after the initial establishment of such orders for women in China, then she is one of the very first women that we know of to have held such ranks. As such, we are incredibly fortunate to have her biography. Her biography, however, tells not of a Buddhist woman who cloistered herself in her temple, meditating and avoiding contact with men and political strife. Instead, her biography tells of a woman whose Buddhist affiliation allowed her to engage in 
the highest echelons of social life in new and surprising ways-as a manager of them.

Her biography, therefore, both confirms and counters information we have about early female Buddhist monastics in China from the Lives of the Nuns. From that text, we learn the story of the establishment of female monastic orders in China and both Sengzhi's dates, as well as her Northern/Southern location, provide outside verification that the story could plausibly be true. Since we see in that text that women came from all over the empire to be ordained in the Liu-Song, and since we may be able to place Sengzhi there, her biography provides further evidence of the historical veracity of that story. However, as a model of virtuosi Buddhist womanhood, Sengzhi's entombed biography tells us a different story than do many of the biographies of women in the Lives of the Nuns. As the translator of that text, Katherine Tsai has made known to us that many of the women whose biographies are contained in the Lives of the Nuns were women of high rank who enjoyed 'an easy concourse with high government officials, nobility, and members of the royal family, including the emperors themselves' ${ }^{58}$ And yet, as Bret Hinsch argues, the biographies in the Lives of the Nuns were composed significantly later than the lives of the women they biographize and, more importantly, were written to appeal to a Confucian sense of decorum and social belonging. ${ }^{59}$ Therefore, the women in the Lives of the Nuns are often praised for evading political life even as they belonged to the political elite. In that text, where nuns do journey out into the social worlds of medieval China, they are praised for resisting rape and capture by licentious men-a Confucian trope. ${ }^{60}$ Sengzhi, on the other hand, lived a fully public life in the imperial realm where she was constantly interacting with the men of that court; however, her virtue in no way relied on her

\footnotetext{
58 Tsai, Lives of the Nuns, 8.

59 Hinsch, 'Confucian Filial Piety', especially 54ff.

60 For example, there is the biography of Zhixian 智賢 (300-370 CE) who
} was stabbed more than twenty times for successfully resisting rape by the Prefect Du Ba 杜霸, of whom nothing else is known (T no. 2063: 935a26-935b13). 
escaping their dangerous advances, though it did rely on her being trusted to hold celibate office among them.

In sum, though Sengzhi's entombed biography offers substantial and early detail regarding what the practice of a virtuoso Buddhist nun looked like in the late-fifth/early sixth-century, what is most noteworthy about her life is simply that she was able to live it in the way that she did. As a woman modeling a new form of womanhood on the rise in the worlds of her time-virtuosi Buddhist monastic womanhood-Sengzhi's story forces the reader to contend with an undeniable historical fact: gender paradigms are constantly shifting and Early Medieval China-with all its Northern-ness and all its Buddhism-is one such time where we see a significant change in the way that women became women, so to speak. With the option of Buddhist renunciation available to them, women were able to take up social roles that they were not able to before. Until now, scholarly worlds were only able to get a glimpse of these roles through the Lives of the Nuns; however, with the introduction of the study of entombed biography to the study of Buddhism, our scholarly understanding of what early East Asian nuns did with their status is one that stands to be radically re-envisioned.

\section{Bibliography}

\section{Abbreviations}

Taishō shinshū daizōkyō大正新脩大蔵経. See Bibliography, Secondary Sources, Takakusu and Watanabe, eds.

X Shinsan Dai Nibon zoku zōkyō 新纂大日本續藏經. See

Bibliography, Secondary Sources, Kawamura, ed.

\section{Primary Sources}

Biqiuni zhuan 比丘尼傳 [Lives of the Nuns]. 4 juan. By Baochang 寶 唱 (495?-528?). T no. 2063, vol. 50.

Da boniepan jing 大般涅槃經 [Nirvāna-sütra]. 40 juan. Translated by

Tanwuchen 曇無讖 (Dharmakșema, 385-433). T no. 374, vol. 12. 
Da Tang Da Cien si sanzang fashi zhuan 大唐大慈恩寺三藏法師 傳 [Biographies of the Tripitaka Masters from the Great Ci'en Monastery in the Great Tang]. 10 juan. Completed by Yancong 彥悰 (active mid-7th c.) in 688 on the basis of a version left by Huili 慧立 (615-?). T no. 2053, vol. 50.

Dajue si biqiuyuanni muzbiming 大覺寺比丘元尼墓誌銘 [The entombed biography for the bhiksuni of the Yuan family from the Great Awakening Nunnery]. Completed in 529. Included in Zhao (comp.), Han Wei Nanbeichao muzhi buibian, 261.

Luoyang qielan ji 洛陽伽藍記 [Record of Buddhist Monasteries in Luoyang]. 5 juan. By Yang Xuanzhi 楊街之 (d.u.). T no. 2092, vol. 51.

Miaofa lianbua jing 妙法蓮華經 [Lotus Sūtra; Skt.

Saddharmapundarika-sütra]. 7 juan. Translated by Jiumoluoshi 鳩摩羅什 (Kumārajīva, 344-413) in 406. T no. 262, vol. 9.

Miaojing wenju sizhi ji 妙經文句私志記 [A Record of Personal Memos on Textual Explanation of the Marvelous Scripture]. 14 juan. By Zhiyun 智雲 (d.u.). X no. 596, vol. 29.

Nanqi shu 南齊書 [Book of the Southern Qi]. 59 juan. Compiled by Xiao Zixian 蕭子顯 (489-537 CE) in 537 CE. Beijing: Zhonghua shuju 中華書局, 2009.

Shengman shizibou yisheng da fangbian fangguang jing 勝鬘師子吼 一乘大方便方廣經 [Sūtra of Queen Śrīmālā of the Lion's Roar; Skt. *Śrimālādevi-siṃha-nāda-sūtra]. 1 juan. Translated by Gunabhadra 求那跋陀羅 (394-468) in 436. T no. 353, vol. 12. Shizong hou Gao Ying muzhi 世宗后高英墓誌 [Entombed Biography of Gao Ying, Empress to Shizong] (i.e. Wei Yaoguang si ni Ciyi muzhiming 魏瑤光寺尼慈義墓誌銘 [Entombed biography for the nun Ciyi of the Yaoguang si of Wei]). Completed in 518. Included in Zhao (comp.), Han Wei Nanbeichao muzhi buibian, 102.

Wei gu biqiuni Ciqing (Wang Zhong'er) muzhiming 魏故比丘尼慈 慶 (王鍾兒) 墓志銘 [The entombed biography of the (Northern) Wei bhikșuñ Ciqing (Wang Zhong'er)]. Dated the seventh day of the fifth month of the fifth year of the Zhengguang 正光 Reign (June 23, 524). Included in Zhao, comp., Han Wei Nanbeichao muzhi buibian, 146. 
Wei gu biqiuni Tong fashi Shi Sengzhi muzhiming 魏故比丘尼 統法師釋僧芝墓誌銘 [The Entombed Biography of the Wei Superintendent of the Bhiksuniss, the Dharma Master, Shi Sengzhi]. Included in Zhao and Zhao, eds., Heluo muke shilling, 20.

Wei gu Zhaoxuan shamen datong sengling fashi muzhiming 魏 故昭玄沙門大統僧令法師墓誌銘 [The entombed biography of the Northern Wei Dharma Master Sengling and Great Superintendent of the Śramanas, who Clarifies Profundities]. Included in Zhao (comp.), Han Wei Nanbeichao muzhi buibian, 311.

Wei shu 魏書 [Book of the Wei] 114 juan. By Wei Shou 魏收 (506572 CE) between 551-554 CE. Beijing: Zhonghua shuju 中華書 局, 2009.

Yaoboduo gongde bei 姚伯多功德碑 [The Stele Memorializing the Merits of Yao Boduo]. Erected in 496. Beijing tushuguan Jinshizu (comp.), Beijing Tushuguan cang Zhongguo lidai shike taben buibuan, vol. 3, 26-28.

\section{Secondary Sources}

Balkwill, Stephanie. 'When Renunciation Is Good Politics: The Women of the Imperial Nunnery of the Northern Wei (386534)'. Nan Nü: Men, Women, and Gender in China 18, no. 2 (2016): 224-56.

Beijing tushuguan Jinshizu 北京圖書館金石組, comp. Beijing

Tushuguan cang Zhongguo lidai shike taben buibuan 北京圖書館 藏中國歷代石刻拓本匯編 [A Compilation of Rubbings of Stone Epitaphs from Chinese History Held in the Collection of the National Library of China]. 100 vols. Zhengzhou: Zhongzhou guji chubanshe 中州古籍出版社, 1989.

Bokenkamp, Stephen R. 'The Yao Boduo Stele as Evidence for the "Dao-Buddhism" of the Early Lingbao Scriptures'. Cabiers d'Extrême-Asie [Journal of East Asian Studies] 9 (1996): 55-67. Chikusa, Masaaki. 'The Formation and Growth of Buddhist Nun Communities in China'. In Engendering Faith: Women and Buddhism in Premodern Japan, edited by Barbara Ruch, 3-20. 
Ann Arbor: University of Michigan Press, 2002.

Heirman, Ann. 'Chinese Nuns and Their Ordination in Fifth Century China'. Journal of the International Association of Buddhist Studies 24, no. 2 (2001): 275-304.

Hinsch, Bret. 'Confucian Filial Piety and the Construction of Ideal Chinese Buddhist Women'. Journal of Chinese Religions 30 (2002): 49-75.

Hucker, Charles. A Dictionary of Official Titles in Imperial China. Stanford: Stanford University Press, 1985.

Kawamura Kōshō 河村孝照, ed. Shinsan Dai Nihon zoku zōkyō 新纂 大日本續藏經 [Revised Edition of the Kyoto Supplement to the Manji Edition of the Buddhist Canon]. 90 vols. Tokyo: Kokusho Kankōkai 國書刊行會, 1975-1989. Reprint of Nakano, et al., comps., Dai Nibon zoku zōkyō.

Kieffer-Pulz, Petra. 'Review of Jonathan Silk's Managing Monks. Administrators and Administrative Roles in Indian Buddhist Monasticism'. Indo-Iranian Journal 53 (2010): 71-88.

Kuramoto Hisanori 倉本尚徳. 'Koku kyō kara mita gyō no bukkyō: Ko Nankai sekkutsu • Kita Kyōdōzan sekkutsu o chūshin ni’ 刻 経から見た鄴の仏教: 小南海石窟・北響堂山石窟を中心に [The Buddhism of Ye as seen from inscriptions: Inside of Xiaonanhai Cave and the Northern Xiangtan cave]. Chügoku kōkogaku 中國 考古學 [Chinese Archeology] 16 (November 2016): 77-101.

Nakano Tatsue 中野達慧, et al., comps. Dai Nibon zoku zōkyō大日 本續藏經 [Extended Buddhist Canon of Great Japan], 120 cases. Kyoto: Zōkyō shoin 藏經書院, 1905-1912.

Silk, Jonathan. Managing Monks: Administrators and Administrative Roles in Indian Monastic Buddhism. Oxford: Oxford University Press, 2008.

Takakusu Junjirō 高楠順次郎, and Watanabe Kaigyoku 渡邊海旭, eds. Taishō shinshū daizōkyō 大正新修大藏經 [Buddhist Canon Compiled under the Taishō Era (1912-1926)]. 100 vols. Tokyo: Taishō issaikyō kankōkai 大正一切經刊行會, 1924-1932.

Tsai, Kathryn. Lives of the Nuns: Biographies of Chinese Nuns from the Fourth to Sixth Centuries, A Translation of the Pi-Ch'in Ni Chuan, Compiled by Shib Pao-Ch'ang. Honolulu: University of Hawai'i Press, 1994. 
Wang Shan 王珊. 'Beiwei Sengzhi muzhi kaoyi' 北魏僧芝墓誌考釋 [A Study and Explanation of the Tomb Inscription of Northern Wei Sengzhi]. Beida shixue 北大史學 [Peking University Archaeology] 13 (August 2008): 87-107.

Wayman, Alex, and Hideko Wayman. The Lion's Roar of Queen Srimālā: Translation of the Lost Sanskrit Work Made from a Collation of the Chinese, Japanese, and Tibetan Versions. New York: Columbia University Press, 1974.

Zhao Chao 趙超, comp. Han Wei Nanbeichao muzhi buibian 漢 魏南北朝墓誌彙編 [A Collection of Tomb Inscriptions from the Han, Wei, and Northern and Southern Dynasties]. Tianjin: Tianjin guji chubanshe 天津古籍出版社, 2008.

Zhao Junping 趙君平, and Zhao Wencheng 趙文成, eds. Heluo muke shiling 河洛墓刻拾零 [A Collection of Tomb Inscriptions from Luoyang, Henan]. Beijing: Beijing tushuguan chubanshe 北京圖 書館出版社, 2006. 